\title{
Burnout Syndrome among Dental professors: a cross-sectional study
}

\author{
Vanessa Leandro Nascimento*; Saulo Fernando Revorêdo*; Eduarda Helena Leandro Nascimento**; \\ Danieli Moura Brasil**; Deborah Queiroz Freitas***; Georgina Agnelo Lima****
}

* DDS, School of Dentistry, Federal University of Pernambuco, UFPE

** PhD Student, Piracicaba Dental School, University of Campinas, UNICAMP

*** PhD, Professor, Piracicaba Dental School, University of Campinas, UNICAMP

**** PhD, Professor, School of Dentistry, Federal University of Pernambuco, UFPE

Received Nov. 8, 2017. Approved March 18, 2018.

\begin{abstract}
Burnout Syndrome (BS) is characterized by stress and exhaustion related to work and affects professionals from different fields. The purpose of this study was to evaluate the prevalence of BS among professors of a Brazilian Dental School and to investigate whether there are sociodemographic factors associated with this condition. Forty-eight out of 72 dental professors $(66.7 \%)$ participated in the survey. Data were collected through a sociodemographic questionnaire adapted from the Copenhagen Burnout Inventory (CBI), which analyzes this condition in four dimensions: personal burnout (PB), work-related burnout (WRB), coworker-professor-related burnout (CWPRB) and patient-related burnout (PRB). Descriptive analysis, Student's t-test and ANOVA test were performed. Among the responders, $60.4 \%$ had graduated from a Dental School more than 15 years, and $64.6 \%$ worked as clinical professors. The highest average scores corresponded to dimensions WRB (2.51) and PB (2.43), while the lowest was related to CWPRB (1.96) and PRB (1.81). Scores were not related to gender, time since graduation or years of teaching experience. Most subjects rated working conditions as "regular" (43.7\%) and "poor" (29.2\%), with significant differences concerning the variable materials and equipment. In conclusion, some respondents have shown a trend to present BS, above all in the PB and WRB dimensions. Similar studies should be performed in different Dental Schools to know the syndrome presence and prevent its development or progression.
\end{abstract}

Descriptors: Dental Faculty. Dentistry. Higher Education. Stress, Psychological. Professional Burnout. 


\section{INTRODUCTION}

Work can be defined as a healthy experience that contributes to one's quality of life, as it is of great importance for daily life ${ }^{1}$. Work not only affects the formation of an individual's social identity but also fosters social integration because of its economic and cultural aspects $^{2}$. Yet, that which should be the source of financial independence and personal fulfillment can become a burden that leads to psychological disorders resulting from work-related exhaustion and stress $^{3}$.

The study of occupational health conditions allows for the characterization of the work processes that may determine patterns of illness among workers. Since associations between labor and health conditions can be identified, preventive or curative interventions may be put forward to address the problem at hand $^{4}$. In general, healthy individuals are associated with productivity, quality and personal fulfillment. On the other hand, unhealthy workers have lower productivity and effectiveness, which is harmful to the individual and to the employer ${ }^{3}$.

Burnout Syndrome (BS) is a major psychosocial problem that affects the quality of professionals and students' lives ${ }^{5,6}$. The term "burnout" derives from the combination of burn (burning) and out (outside), indicating a physical, emotional and mental exhaustion caused by a mismatch between the individual and the work environment ${ }^{3}$. This term was first used by Freudenberger $^{7}$, when referring to a process defined as a sense of failure and exhaustion caused by excessive depletion of energy resources, compound by fatigue behavior, depression, annoyance, work overload and stiffness.

Studies indicated that educators are significantly affected by Burnout syndrome ${ }^{8,9}$. Various factors interfere with the development and progression of Burnout syndrome, which makes it a challenging condition to diagnose and prevent. Among health professionals, dentists are at risk for developing the syndrome ${ }^{10}$.

Clinical dental practice carries the risk of several occupational diseases related to work ergonomics, interpersonal matters and biohazards ${ }^{10}$. Dentists know these risks well as they are usually covered and discussed in the undergraduate and postgraduate curricula. In addition, psychological disorders are also reported as a possible consequence of daily dental practice among general dentists ${ }^{10}$, graduate $^{\text {specialists }}{ }^{6}$, undergraduate ${ }^{11,12}$ and postgraduate dental students ${ }^{13}$. However, the knowledge about BS related to dental professors is still little explored in the literature.

Understanding the signs and symptoms, as well as to determine the prevalence of this syndrome is extremely important for developing preventive and interventional programs, which may improve an individual's quality of life and, hence, the quality of delivered services ${ }^{14,15}$. Since dentists and educators are risk groups for developing BS, the objective of this study was to determine the prevalence of BS among dental professors and to identify any possible sociodemographic characteristics that could be related to this condition.

\section{METHODS}

This cross-sectional study was approved by the Ethics Committee on Human Research of the Health Science Center, Federal University of Pernambuco, Brazil (protocol \#10654812. 3.0000.5208).

Data collection involved the application of questionnaires to the faculty of the Dental School, Federal University of Pernambuco. Out of 72 professors, the sample consisted of 48 individuals $(66.7 \%)$ who had graduated from dental school and signed the informed consent. 
Two self-administered questionnaires that had been validated for reproducibility were used to collect the data for this research, and a pilot study was conducted with $25 \%$ of the total sample to verify the applicability of the proposed methodology. From January to June 2013, the dental professors were visited by the authors and asked to respond to a socio-demographic questionnaire and to the Copenhagen Burnout Inventory (CBI) questionnaire, which was originally proposed by Kristensen et al. ${ }^{16}$ and adapted to the needs of this study. The sociodemographic questions were related to gender, time since graduation in years, years working in a dental school, workplace, rank, and performance at work. Perceptions of work conditions were assessed by means of a fivepoint scale, as follows: terrible, poor, regular, good or excellent.

The original CBI is composed of three dimensions (personal burnout, work-related burnout and, client-related burnout). Since dental professors deal with patients as well as with coworkers-professors, we made an adapted version of CBI by duplicating the last dimension to add a fourth one, as follows: personal burnout (PB), work-related burnout (WRB), coworkerprofessor-related burnout (CWPRB) and patientrelated burnout (PRB) dimensions.

The adapted CBI questionnaire contained 25 questions with responses ranging from: always (score 4); often (score 3); sometimes (score 2); rarely (score 1); and never (scoring 0). Respondents were considered to have BS if the scores average was equal to 4 in a separate dimension.

Data were tabulated and analyzed using SPSS version 21 (Statistical Package for Social Sciences). Comparison between two or more than two categories was performed using student's t-test and ANOVA, respectively, when data were normal. When ANOVA identified significant differences between the categories, post-hoc Tukey's multiple comparisons test was used. The Mann-Whitney and Kruskal-Wallis tests were performed when data normality was rejected. Normality was verified with the Shapiro-Wilk test, and verification of the hypothesis of equal variances was performed using Levene's F test. The level of statistical significance was set at $5 \%$.

\section{RESULTS}

Respondents' sociodemographic characteristics are shown in table 1. Most dental professors were women $(62.5 \%)$, with more than 15 years since graduation $(60.4 \%)$, over 15 years of working at the university (54.2\%) and holding clinical positions (64.6\%). Approximately $40.0 \%$ of subjects were holding or had held administrative(s) position(s), which referred to assistant chief, administrator chief, course coordinator, responsible for the postgraduate course, integrated clinic or laboratory. Since an individual could work in more than one location and have more than one administrative or clinical position, the sum of absolute frequencies (percentages) exceeded 48 responses $(100 \%)$ in some instances. Table 2 presents the distribution of the perceptions of work conditions, which were mostly regular.

The distribution of the answers to the adapted Copenhagen Burnout Inventory is shown in table 3. The questions were distributed in the following sequence: Q1 to Q6 about PB, Q7 to Q13 about WRB, Q14 to Q19 about CWPRB and Q20 to Q25 about PRB. "Never” answers (score 0 ) have a positive meaning, followed by "rarely" (score 1), "sometimes" (score 2), "often" (score 3) and "always" (score 4), the latter having a negative meaning. The most frequent answers were "rarely" (25 to $50 \%$ ) and "never" (6.2 to $52.1 \%$ ), corresponding to scores 1 and 0 , respectively. On the other hand, Q10 must be interpreted inversely, since "never" and "always" 
have a negative and positive meaning, respectively. For Q10, the most frequent answers were "often" (41,7\%) and "sometimes" (20,8\%).

Table 4 shows the relation between the sociodemographic and work-related variables and the four BS dimensions. The highest averages corresponded to the dimensions Work (2.51) and Personal (2.43), and the lowest averages corresponding to the dimensions Colleagues (1.96) and Patients (1.81).

Significant differences were found for the perception of materials and equipment in the Personal $\quad(p=0.049)$, Work $(p=0.011)$ and
Coworker-professor dimensions $(\mathrm{p}=0.031)$. The "terrible/poor" showed significantly higher values compared to "good/excellent" category in the personal and work dimensions, while "terrible/poor" showed significantly higher values when compared to "regular" category in coworker-professor dimension. In terms of the work dimensions' distribution, $41.7 \%$ of the respondents perceived material and equipment as "regular" and $22.9 \%$ as "poor", thus associating with statistically significant differences observed in the dimensions: personal (2.50), work (2.71) and colleagues (1.67).

Table 1. Sociodemographic profile of the respondents

\begin{tabular}{lccc}
\hline Variable & $\mathbf{n}(\mathbf{\%})$ & Variable & $\mathbf{n}(\mathbf{\%})$ \\
\hline Gender & & In an administrative position? & \\
Male & $18(37.5)$ & Yes & $19(39.6)$ \\
Female & $30(62.5)$ & Not & $29(60.4)$ \\
Time since graduation & & Position ${ }^{(1)}$ & \\
$<15$ & $19(39.6)$ & Not in as administrative position & $29(60.4)$ \\
$>15$ & $29(60.4)$ & Chief administrator & $4(8.3)$ \\
Time teaching in public service & & Chief assistant & $2(4.2)$ \\
$<15$ & $22(45.8)$ & Course coordinator & $3(6.2)$ \\
$>15$ & $26(54.2)$ & Post graduate & $3(6.2)$ \\
Workplace ${ }^{(1)}$ & & Integrated clinical & $4(8.3)$ \\
Emergency care & $3(6.2)$ & Laboratory & $5(10.4)$ \\
Laboratory & $18(37.5)$ & Category & $16(33.3)$ \\
Administrative & $4(8.3)$ & Temporary professor & $24(50)$ \\
School clinic & $31(64.6)$ & Permanent professor & $5(10.4)$ \\
Curricular traineeship & $3(6.2)$ & Associate professor & $3(6.2)$ \\
Classroom & $2(4.2)$ & Not informed & \\
\hline
\end{tabular}

(1): Considering that a respondent could work in more than one place and occupy more than one position, the sum of the frequencies is greater than the total (48 faculty - 100\%).

Table 2. Distribution of perceptions related to work conditions

\begin{tabular}{lccccc}
\hline \multirow{2}{*}{\multicolumn{1}{c}{ Variable }} & \multicolumn{5}{c}{ Answers n (\%) $)^{(\mathbf{1})}$} \\
\cline { 2 - 6 } & Terrible & Poor & Regular & Good & Excellent \\
\hline Work conditions & $3(6.2 \%)$ & $14(29.2 \%)$ & $21(43.7 \%)$ & $9(18.8 \%)$ & $1(2.1 \%)$ \\
Workplace facilities & $5(10.4 \%)$ & $11(22.9 \%)$ & $19(39.6 \%)$ & $11(22.9 \%)$ & $2(4.2 \%)$ \\
Materials and equipment & $3(6.2 \%)$ & $11(22.9 \%)$ & $20(41.7 \%)$ & $13(27.1 \%)$ & $1(2.1 \%)$ \\
\hline
\end{tabular}

(1): Percentage values were obtained from the 48 respondents. 
Table 3. Distribution of answers to the adapted Copenhagen Burnout Inventory

\begin{tabular}{|c|c|c|c|c|c|}
\hline \multirow[b]{2}{*}{ Variable } & \multicolumn{5}{|c|}{ Answers n (\%) } \\
\hline & $\begin{array}{c}\text { Never } \\
\text { (score 0) }\end{array}$ & $\begin{array}{c}\text { Rarely } \\
\text { (score 1) }\end{array}$ & $\begin{array}{l}\text { Sometimes } \\
\text { (score 2) }\end{array}$ & $\begin{array}{c}\text { Often } \\
\text { (score 3) }\end{array}$ & $\begin{array}{l}\text { Always } \\
\text { (score 4) }\end{array}$ \\
\hline \multicolumn{6}{|l|}{ Personal Burnout } \\
\hline Q1 - How often do you feel tired? & $3(6.2)$ & $16(33.3)$ & $19(39.6)$ & $9(18.8)$ & $1(2.1)$ \\
\hline Q2 - How often are you physically exhausted? & $4(8.3)$ & $18(37.5)$ & $18(37.5)$ & $7(14.6)$ & $1(2.1)$ \\
\hline Q3 - How often are you emotionally exhausted? & $7(14.6)$ & $21(43.7)$ & $12(25.0)$ & $6(12.5)$ & $2(4.2)$ \\
\hline $\begin{array}{l}\text { Q4 - How often do you think: "I can't take it } \\
\text { anymore"? }\end{array}$ & $15(31.2)$ & $20(41.7)$ & $9(18.8)$ & $4(8.3)$ & - \\
\hline Q5 - How often do you feel worn out? & $9(18.8)$ & $20(41.7)$ & $14(29.2)$ & $5(10.4)$ & - \\
\hline $\begin{array}{l}\text { Q6 - How often do you feel weak and susceptible to } \\
\text { illness? }\end{array}$ & $7(14.6)$ & $24(50.0)$ & $13(27.1)$ & $3(6.2)$ & $1(2.1)$ \\
\hline \multicolumn{6}{|l|}{ Work-related } \\
\hline $\begin{array}{l}\text { Q7 - Do you feel worn out at the end of the working } \\
\text { day? }\end{array}$ & $3(6.2)$ & $13(27.1)$ & $21(43.7)$ & $9(18.8)$ & $2(4.2)$ \\
\hline $\begin{array}{l}\text { Q8 - Are you exhausted in the morning, at the } \\
\text { thought of another day at work? }\end{array}$ & $14(29.2)$ & $19(39.6)$ & $11(22.9)$ & $2(4.2)$ & $2(4.2)$ \\
\hline $\begin{array}{l}\text { Q9 - Do you feel that every working hour is tiring for } \\
\text { you? }\end{array}$ & $12(25.0)$ & $23(47.9)$ & $9(18.8)$ & $3(6.2)$ & $1(2.1)$ \\
\hline $\begin{array}{l}\text { Q10 - Do you have enough energy for family and } \\
\text { friends during leisure time? (inverse scoring) }\end{array}$ & $2(4.2)$ & $8(16.7)$ & $10(20.8)$ & 20(41.7) & $8(16.7)$ \\
\hline Q11 - Is your work emotionally exhausting? & $5(10.4)$ & $15(31.2)$ & $18(37.5)$ & $6(12.5)$ & $4(8.3)$ \\
\hline Q12 - Does your work frustrate you? & $22(45.8)$ & $18(37.5)$ & $3(6.2)$ & $5(10.4)$ & - \\
\hline Q13 - Do you feel burnt out because of your work? & $9(18.8)$ & $18(37.5)$ & $16(33.3)$ & $5(10.4)$ & - \\
\hline \multicolumn{6}{|l|}{ Co-worker related Burnout } \\
\hline $\begin{array}{l}\text { Q14 - Do you find it hard to work with your } \\
\text { colleagues? }\end{array}$ & $16(33.3)$ & $24(50.0)$ & $6(12.5)$ & $2(4.2)$ & - \\
\hline $\begin{array}{l}\text { Q15 - Does it drain your energy to work with your } \\
\text { colleagues? }\end{array}$ & $16(33.3)$ & $20(41.7)$ & $11(22.9)$ & $1(2.1)$ & - \\
\hline $\begin{array}{l}\text { Q16- Do you find frustrating to work with your } \\
\text { colleagues? }\end{array}$ & $22(45.8)$ & $16(33.3)$ & $9(18.8)$ & $1(2.1)$ & - \\
\hline $\begin{array}{l}\text { Q17 - Do you feel that you give more than you get } \\
\text { back when you work with your colleagues? }\end{array}$ & $12(25.0)$ & $16(33.3)$ & $14(29.2)$ & $3(6.2)$ & $3(6.2)$ \\
\hline $\begin{array}{l}\text { Q18 - Are you tired of working with your } \\
\text { colleagues? }\end{array}$ & $20(41.7)$ & $14(29.2)$ & $11(22.9)$ & $2(4.2)$ & $1(2.1)$ \\
\hline $\begin{array}{l}\text { Q19-Do you sometimes wonder how long you will } \\
\text { be able to continue working with your colleagues? }\end{array}$ & $24(50.0)$ & $12(25.0)$ & $8(16.7)$ & $2(4.2)$ & $2(4.2)$ \\
\hline \multicolumn{6}{|l|}{ Patients related Burnout } \\
\hline Q20 - Do you find it hard to work with patients? & $15(31.2)$ & $21(43.8)$ & $12(25.0)$ & - & - \\
\hline $\begin{array}{l}\text { Q21 - Does it drain your energy to work with } \\
\text { patients? }\end{array}$ & $17(35.4)$ & $20(41.7)$ & $11(22.9)$ & - & - \\
\hline Q22 - Do you find frustrating to work with patients? & $22(45.8)$ & $24(50.0)$ & $2(4.2)$ & - & - \\
\hline $\begin{array}{l}\text { Q23 - Do you feel that you give more than you get } \\
\text { back when you work with patients? }\end{array}$ & $14(29.2)$ & $17(35.4)$ & $14(29.2)$ & $3(6.2)$ & - \\
\hline Q24 - Are you tired of working with patients? & $25(52.1)$ & $16(33.3)$ & $7(14.6)$ & - & - \\
\hline $\begin{array}{l}\text { Q25 - Do you sometimes wonder how long you will } \\
\text { be able to continue working with patients? }\end{array}$ & $24(50.0)$ & $16(33.3)$ & $6(12.5)$ & $1(2.1)$ & $1(2.1)$ \\
\hline
\end{tabular}

(1) Percentage values were obtained based on number of respondents $(n=48)$. 
Table 4. Mean, standard deviation and median of the CBI dimensions according to demographic and workrelated variables. The scores could range from 0 to 4 , respectively, from the lowest to the highest feeling of professional exhaustion

\begin{tabular}{lcccc}
\hline \multirow{2}{*}{ Variable } & \multicolumn{3}{c}{ Copenhagen Burnout Inventory - Mean \pm SD (Median) } \\
\cline { 2 - 5 } & Personal & Work & Coworker-professor & Patients \\
\hline Total group & $2.43 \pm 0.8$ & $2.51 \pm 0.6$ & $1.96 \pm 0.7$ & $1.81 \pm 0.6$ \\
Gender & & & & \\
Male & $2.33 \pm 0.7(2.33)$ & $2.40 \pm 0.5(2.57)$ & $2.02 \pm 0.6(2.00)$ & $1.87 \pm 0.6(2.08)$ \\
Female & $2.48 \pm 0.8(2.33)$ & $2.58 \pm 0.6(2.57)$ & $1.93 \pm 0.8(1.83)$ & $1.78 \pm 0.7(1.83)$ \\
& $\mathrm{p}^{(1)}=0.520$ & $\mathrm{p}^{(1)}=0.350$ & $\mathrm{p}^{(2)}=0.467$ & $\mathrm{p}^{(2)}=0.645$
\end{tabular}

Time since graduation

$$
\begin{array}{ccccc}
<15 \text { years } & 2.45 \pm 0.8(2.50) & 2.59 \pm 0.8(2.57) & 1.73 \pm 0.6(1.67) & 1.75 \pm 0.7(1.67) \\
>15 \text { years } & 2.41 \pm 0.8(2.33) & 2.46 \pm 0.5(2.57) & 2.11 \pm 0.7(2.00) & 1.86 \pm 0.6(2.00) \\
& \mathrm{p}^{(1)}=0.885 & \mathrm{p}^{(1)}=0.498 & \mathrm{p}^{(2)}=0.058 & \mathrm{p}^{(1)}=0.551
\end{array}
$$

Time teaching in public service

$$
\begin{aligned}
& <15 \text { years } \\
& >15 \text { years }
\end{aligned}
$$

$$
2.56 \pm 0.8(2.42)
$$

$2.58 \pm 0.7(2.50)$

$1.86 \pm 0.7(1.83)$

$1.93 \pm 0.6(2.00)$

$2.31 \pm 0.7(2.17)$

$2.46 \pm 0.6(2.57)$

$2.05 \pm 0.7(2.00)$

$1.71 \pm 0.6(1.75)$

$$
\mathrm{p}^{(1)}=0.275
$$

$$
\mathrm{p}^{(2)}=0.967
$$

$$
\mathrm{p}^{(1)}=0.341
$$$$
\mathrm{p}^{(2)}=0.239
$$

Work conditions

$$
\begin{array}{lc}
\text { Terrible/Poor } & 2.63 \pm 0.8(2.67) \\
\text { Regular } & 2.47 \pm 0.7(2.33) \\
\text { Good/Excelent } & 2.00 \pm 0.8(1.92) \\
& \mathrm{p}^{(3)}=0.117
\end{array}
$$$$
2.65 \pm 0.6(2.71)
$$$$
1.89 \pm 0.7(2.00)
$$$$
1.76 \pm 0.6(2.00)
$$$$
2.54 \pm 0.6(2.57)
$$$$
2.00 \pm 0.8(1.83)
$$$$
1.79 \pm 0.6(1.83)
$$$$
2.21 \pm 0.5(2.07)
$$$$
2.00 \pm 0.6(2.00)
$$$$
1.95 \pm 0.8(1.92)
$$

$$
\mathrm{p}^{(3)}=0.196
$$

$$
\mathrm{p}^{(3)}=0.882
$$$$
\mathrm{p}^{(4)}=0.737
$$

Facilities

$$
\begin{array}{lc}
\text { Terrible/Poor } & 2.51 \pm 0.7(2.33) \\
\text { Regular } & 2.60 \pm 0.8(2.50) \\
\text { Good/Excelent } & 2.08 \pm 0.8(2.00) \\
& \mathrm{p}^{(3)}=0.152
\end{array}
$$$$
2.73 \pm 0.7(2.71)
$$$$
1.97 \pm 0.8(1.92)
$$$$
1.96 \pm 0.6(2.08)
$$$$
2.51 \pm 0.5(2.57)
$$$$
2.06 \pm 0.7(2.00)
$$$$
1.78 \pm 0.6(1.83)
$$

$2.24 \pm 0.5(2.00)$

$1.81 \pm 0.7(1.67)$

$1.68 \pm 0.7(1.50)$

$$
\mathrm{p}^{(3)}=0.611
$$$$
\mathrm{p}^{(3)}=0.473
$$

Materials and equipment

$$
\begin{array}{lcccc}
\text { Terrible/Poor } & 2.70 \pm 0.9(2.50)^{\mathrm{A}} & 2.79 \pm 0.8(2.71)^{\mathrm{A}} & 1.68 \pm 0.7(1.67)^{\mathrm{A}} & 2.01 \pm 0.6(2.08) \\
\text { Regular } & 2.52 \pm 0.7(2.50)^{\mathrm{AB}} & 2.59 \pm 0.4(2.57)^{\mathrm{AB}} & 2.27 \pm 0.6(2.17)^{\mathrm{B}} & 1.88 \pm 0.6(2.00) \\
\text { Good/Excelent } & 2.02 \pm 0.7(2.00)^{\mathrm{B}} & 2.13 \pm 0.5(2.07)^{\mathrm{B}} & 1.81 \pm 0.7(1.67)^{\mathrm{AB}} & 1.51 \pm 0.6(1.25) \\
& \mathrm{p}^{(3)}=0.049^{*} & \mathrm{p}^{(3)}=0.011^{*} & \mathrm{p}^{(3)}=0.031^{*} & \mathrm{p}^{(4)}=0.108
\end{array}
$$

(*): Significant difference at 5\%. (1)Student's t-test with equal variances. (2) Mann Whitney test. (3) F (ANOVA) test. (4) Kruskal Wallis test. Different letters mark a significant difference between the categories according to Tukey's pairwise comparisons. 
The analysis considered the respondent affected by Burnout syndrome if the average was 4 in at least a separate dimension. Two (4.2\%) Dental professors have shown a tendency to present personal burnout (score 3.7), and one professor $(2.1 \%)$ had signs of work-related burnout (score 3.7), but none with coworkerprofessor or patient-related burnout.

\section{DISCUSSION}

This study analyzed the prevalence of Burnout syndrome among the dental professors of one public university in Brazil, taking into account several aspects related to work conditions and interpersonal relations. While belonging to professional groups known to be at risk for developing the syndrome, surprisingly we did not identify it in any of the respondents. Nevertheless, we noticed that work conditions could be a stressing factor in the daily practice of these professionals, even though this was not a general finding.

The process of burnout occurs at a personal level and its progression may take decades. It appears gradually and progresses almost unperceptively, and the affected individual is usually on denial ${ }^{3}$. Since 1999, the Brazilian law defines Burnout syndrome as clinical exhaustion derived from exposure to prolonged emotional and interpersonal stress at work ${ }^{17}$.

Most scientific studies regarding BS are based on the Maslach Burnout Inventory $(\mathrm{MBI})^{3,6,11,15}$, which separates the syndrome into three dimensions: exhaustion, cynicism, and professional efficacy. However, there are other measurement instruments, particularly the CBI developed by Kristensen et al. ${ }^{16}$ Its use is recommended for any type of work activity and has proven to be an effective and reliable method ${ }^{18}$. Our choice for the CBI was based on a study by Winwood and Winefield ${ }^{18}$, which concluded that $\mathrm{CBI}$ has excellent psychometric properties, being more accurate a tool for the assessment of burnout among health professionals than MBI. In addition, the evaluation of the four dimensions studied in the CBI allowed a better understanding of the different aspects related to the possible sources of stress and professional exhaustion of the teacher (burnout related to work, coworkers, personal, and patients' issues).

Winwood and Winefield ${ }^{18}$ applied CBI as a measurement tool for BS among Australian dentists and found the prevalence to be especially high in the dimensions PB (16.9\%) and WRB $(13.2 \%)$. Here, we found the highest values for those same dimensions, but with lower percentages (PB, 4.2\%; WRB, 2.1\%). On the other hand, considering the overall assessment, none of the respondents obtained the score (4.0) necessary to be considered as affected by the syndrome.

Our results showed that the respondents' perception of work conditions was negative, being classified mostly as "poor" or "regular". These conditions referred to both the workload and multiple responsibilities as the materials and equipment available in their work environment. Thus, there is a need for better planning and distribution of teaching activities, and investments in new resources to improve the infrastructure of Dental schools to prevent these factors from becoming triggers for burnout ${ }^{14}$. Still, a relationship between the work conditions and the development of SB was not observed. One explanation would be the multiple functions of the dental faculty (classroom, clinical duties, and administrative tasks), which may attenuate the exhaustion derived from monotonous and isolated activities. For instance, faculty members are always in contact with youthful dental students, which may be somehow beneficial; moreover, the academic environment stimulates faculty to be updated in matters clinical and 
scientific. We evaluated these conditions in a cross-sectional manner, however they change over time so that longitudinal studies with a larger sample including several dental schools would offer a better grasp of the problem.

The higher the time since graduation and time at work (respondents who had graduated for 15 years or more), higher scores related to Burnout syndrome were found. That finding was similar to a previous study ${ }^{15}$ and goes in line with the concept presented by Maslach et al., ${ }^{13}$ who stated that burnout appears in the late stages of one's professional career, for the syndrome is the result of long exposure to stress at work. Nevertheless, this does not exclude the possibility that young, less experienced faculty may be at risk for developing the syndrome, since these professionals may have greater difficulties administering the challenges and hardships encountered in their daily lives ${ }^{19}$.

Since our study included only professors from a single school of Dentistry, the number of courses and students did not represent a variable. However, a recent study $^{15}$ using the MBI questionnaire evaluated the prevalence of the Burnout syndrome among professors of undergraduate health courses and found a significant association between the emotional exhaustion and the number of courses the professors teach and the number of students with whom they have daily contact. Despite this interesting finding, these authors did not separate the professors from the different health courses in their results ${ }^{15}$, being relevant that future studies investigate these variables among dental professors only.

While the lack of research on Burnout syndrome among dental professors is clear, and in contrast to the few previous reports ${ }^{15,18,20}$, in our study, none of the respondents was considered affected by the syndrome. Still, there were some individuals that were within the range of work-related and personal burnout.

This study highlights the importance of knowing and investigating stress factors, as well as the presence of BS in order to facilitate early diagnosis among dental professors. Therefore, we also expect employers to be aware of this issue and to implement policies for the prevention of Burnout syndrome since that work conditions might affect not only the quality of provided work but also professional's quality of life.

\section{CONCLUSION}

In conclusion, some respondents have shown signs of BS, above all in the PB and WRB dimensions. Although they had not fulfilled all criteria of Burnout definition, there were signs of stress which uncorrected can lead to the syndrome. Therefore, we suggest that similar studies be conducted in different Dental Schools to evaluate the working environment and professional relations, to thereby to introduce necessary changes improving working conditions and preventing the development or progression of BS.

\section{RESUMO}

Síndrome de Burnout entre professores de Odontologia: um estudo transversal

A Síndrome de Burnout (SB) é caracterizada por estresse e exaustão relacionados ao trabalho, e afeta profissionais de diferentes áreas. O objetivo nesse estudo foi avaliar a prevalência da SB em professores de uma faculdade de Odontologia brasileira, e investigar se existem fatores sociodemográficos associados a essa condição. Quarenta e oito de um total de 72 professores de Odontologia $(66,7 \%)$ participaram do estudo. Os dados foram coletados por meio de um questionário sociodemográfico adaptado a partir do Inventário Burnout de Copenhagen (CBI), que analisa essa condição em quatro dimensões: burnout pessoal (PB), burnout relacionado ao 
trabalho (WRB), burnout relacionado aos colegas de trabalho (CWPRB) e burnout relacionado aos pacientes (PRB). Análises descritivas, testes t-student e ANOVA foram realizados. Entre os participantes, 60,4\% eram graduados em Odontologia há mais de 15 anos, e $64,6 \%$ trabalhavam como professores na clínica. As maiores pontuações médias corresponderam às dimensões WRB $(2,51)$ e PB $(2,43)$, enquanto as menores foram relacionadas ao CWPRB $(1,96)$ e ao PRB $(1,81)$. Os escores não foram relacionados ao gênero, tempo de graduação ou anos de experiência no ensino. A maioria dos entrevistados classificou as condições de trabalho como "regular" (43,7\%) e "ruim" $(29,2 \%)$, com diferenças significantes em relação à variável materiais e equipamentos. Em conclusão, alguns professores mostraram sinais da SB, principalmente nas dimensões PB e WRB. Estudos similares devem ser realizados em diferentes cursos de Odontologia para investigar a presença da síndrome e prevenir seu desenvolvimento ou progressão.

Descritores: Docentes de Odontologia. Educação Superior. Esgotamento Profissional. Estresse Psicológico. Odontologia.

\section{REFERENCES}

1. Noh JW, Kim J, Park J, Kim HJ, Kwon YD. Gender difference in relationship between health-related quality of life and work status. PLoS One. 2015;10(12):e0143579.

2. Reid C, Riddick-Grisham S. The importance of work or productive activity in life care planning and case management. Neuro Rehabilitation. 2015;36(3):267-74.

3. Maslach C, Schaufeli WB, Leiter MP. Job burnout. Annu Rev Psychol. 2001;52(1):397-422.

4. Brandstätter V, Job V, Schulze B. Motivational incongruence and well-being at the workplace: person-job fit, job burnout, and physical symptoms. Front Psychol. 2016;7:1153.
5. Murphy RJ, Gray SA, Sterling G, Reeves K, DuCette J. A comparative study of professional student stress. J Dent Educ. 2009; 73(3):328-37.

6. Porto GG, Carneiro SC, Vasconcelos BC, Nascimento MM, Leal JL. Burnout syndrome in oral and maxillofacial surgeons: a critical analysis. Int J Oral Maxillofac Surg. 2014;43(7):894-9.

7. Freudenberger HJ. Staff burn-out. J Soc Issues. 1974;30(1):159-65.

8. Arvidsson I, Håkansson C, Karlson B, Björk J, Persson R. Burnout among Swedish school teachers - a cross-sectional analysis. BMC Public Health. 2016;16(1):823.

9. Huri $M$, Bağiş $N$, Eren $H$, Başibüyük $O$, Şahin S, Umaroğlu M, et al. Burnout and occupational participation among dentists with teaching responsibilities in universities. Psychol Health Med. 2016;22(6):693-700.

10. Leggat PA, Kedjarune U, Smith DR. Occupational health problems in modern dentistry: a review. Ind Health. 2007;45(5):611-21.

11. Montiel-Company JM, Subirats-Roig C, Flores-Martí P, Bellot-Arcís C, AlmerichSilla JM. Validation of the Maslach Burnout Inventory-Human Services Survey for estimating burnout in Dental students. J Dent Educ. 2016;80(11):1368-75.

12. Pau A, Rowland ML, Naidoo S, AbdulKadir R, Makrynika E, Moraru R, et al. Emotional intelligence and perceived stress in dental undergraduates: a multinational survey. J Dent Educ. 2007;71(2):197-204.

13. Divaris K, Polychronopoulou A, Taoufik K, Katsaros C, Eliades T. Stress and burnout in postgraduate dental education. Eur J Dent Educ. 2012;16(1):35-42.

14. Chirico F. Job stress models for predicting burnout syndrome: a review. Ann Ist Super Sanita. 2016;52(3):443-56. 
15. Prado RL, Bastianini ME, Cavalleri MZ, Ribeiro SFR, Pizi ECG, Marsicano JA. Assessment of Burnout syndrome in university teachers. Rev ABENO. 2017; 17(3):21-9.

16. Kristensen TS, Borritz M, Villadsen E, Christensen KB. The Copenhagen Burnout Inventory: a new tool for the assessment of burnout. Work Stress. 2005;19(3):192-207.

17. Brasil. Doenças relacionadas ao trabalho: Manual de procedimentos para os serviços de saúde. Brasília: Ministério da Saúde, 2001.

18. Winwood PC, Winefield AH. Comparing two measures of burnout among dentists in Australia. Int J Stress Manag. 2004;11(3):282-89.
19. Randall KJ. Examining the relationship between burnout and age among Anglican clergy in England and Wales. Ment Health Rel Cult. 2007;10(1):39-46.

20. Milfont TL, Denny S, Ameratunga S, Robinson E, Merry S. Burnout and wellbeing: testing the Copenhagen Burnout Inventory in New Zealand teachers. Soc Indic Res. 2008;89(1):169-177.

\section{Correspondece to:}

Eduarda Helena Leandro Nascimento

e-mail: eduarda.hln@gmail.com

University of Campinas

Piracicaba Dental School

Department of Oral Diagnosis

Av. Limeira, 901

3414-903, Piracicaba, São Paulo, Brazil. 